\title{
Lihalajin, rasvaprosentin, tuotantotapojen ja hiilijalanjälkitiedon vaikutus kuluttajien jauhelihan valintaan
}

\author{
L. Koistinen ${ }^{1{ }^{*}}$, E. Pouta ${ }^{1)}$, J. Heikkilä $^{1)}$, S. Forsman-Hugg ${ }^{1)}$, J. Kotro ${ }^{1)}$, J. Mäkelä $^{2)}$ and M. Niva ${ }^{2)}$ \\ ${ }^{1)}$ MTT, Latokartanonkaari 9, FI-00790 Helsinki, Finland, nimi.etunimi@mtt.fi \\ ${ }^{2)}$ Kuluttajatutkimuskeskus, P.O. Box 5, FI-00531 Helsinki, Finland, nimi.etunimi@ncrc.fi
}

Kasvanut huolestuneisuus muun muassa ruoan ympäristö- ja terveysvaikutuksista on lisännyt kuluttajien kiinnostusta elintarvikkeiden tuotantomenetelmistä ja muista ominaisuuksista. Aiempien tutkimusten mukaan erityisesti ruoan turvallisuus, luonnonmukainen tuotanto, eläinystävällisyys ja kotimaisuus ovat olleet toivottuja piirteitä lihatuotteilla. Useat tutkimukset ovat korostaneet kuluttajien heterogeenisuuden huomioimisen tärkeyttä, mutta hiilijalanjälkitiedon vaikutusta kuluttajien lihatuotteiden valintaan ei tietääksemme ole tutkittu.

Tämän tutkimuksen tarkoitus on tuottaa tietoa kuluttajien suhteellisista preferensseistä jauhelihatuotteiden ominaisuuksien suhteen, eli paljastaa mitkä tuoteominaisuudet luovat heille eniten lisäarvoa. Tutkimme ensinnäkin vaikuttavatko lihalaji (sika, sika-nauta ja nauta), tuotantotapa (tavanomainen, luonnonmukainen, eläinystävällinen ja tuoteturvallisuuteen ja terveyteen panostava), rasvaprosentti ja hiilijalanjälkitieto kuluttajien valintoihin ja onko näillä tuoteominaisuuksilla yhteisvaikutuksia kuluttajan valintatodennäköisyyteen. Toisekseen tutkimme löytyykö kuluttajista preferenssiensä suhteen toisistaan poikkeavia ryhmiä ja miten nämä ryhmät eroavat toisistaan vastaajien taustatietojen (sosio-demografiat, kulutustottumukset, asenteet) perusteella. Viimeisenä tutkimme kuinka paljon ominaisuudet vaikuttavat kuluttajan halukkuuteen maksaa erilaisista tuotteista ja kuinka maksuhalukkuus poikkeaa ryhmien välillä.

Kuluttajien suhteellisia preferenssejä mitattiin valintakokeella. Aineisto kerättiin internet-pohjaisella kyselylomakkeella, johon vastasi 1623 suomalaista. Valintoja mallinnettiin ehdollisella logistisella regressiolla (conditional logit model) ja kuluttajien heterogeenisuus huomioitiin käyttämällä latenttia luokkamallia (latent class model).

Matalalla rasvaprosentilla oli erityisen positiivinen vaikutus kuluttajien valintaan. Tuotantomenetelmistä luonnonmukaisella tuotannolla oli suurin positiivinen vaikutus verrattuna eläinystävälliseen, turvallisuuteen ja terveyteen panostavaan ja tavanomaiseen tuotantoon. Naudan jauhelihaa suosittiin enemmän kuin sikanaudan tai sian jauhelihaa. Naudan jauhelihalla on suurempi hiilijalanjälki kuin sian jauhelihalla, ja tämän hiilijalanjälkitiedon mainitsemisella oli selvä vaikutus lihatyypin valintaan: naudan jauhelihan suhteellinen suosittuus pieneni hiilijalanjäljen koon mainitsemisen yhteydessä. Analyysissa paljastui kuusi toisistaan eroavaa kuluttajaluokkaa: hintatietoinen (23\% vastaajista), rasvaprosenttitietoinen (20\%), tiedostava mutta passiivinen (17\%), indifferentti (17\%), naudanlihaa arvostava (13\%) ja tuotantotapatietoinen (11\%) kuluttajaryhmä. Kuluttajat olivat valmiita maksamaan erityisesti matalasta rasvaprosentista, mutta heidän maksuhalukkuutensa lihasta ei muuttunut suuresti hiilijalanjälkitiedon mainitsemisen vuoksi. Suhteellinen maksuhalukkuus vaihteli kuitenkin huomattavasti kuluttajasegmenttien välillä.

Asiasanat: Kuluttajapreferenssit; heterogeenisuus; valintakoe; latent class analyysi; maksuhalukkuus; liha.

\footnotetext{
*Vastaava kirjoittaja (L. Koistinen): Puh.: +358 40486 0571; Sähköposti: laura.koistinen@ mtt.fi.
} 


\section{Introduction}

Growing concern over the environmental impacts and different credence characteristics of food has increased consumer interest in the production methods and other attributes of food products (Forsman-Hugg et al., 2008). At the same time, the meat industry in Finland is facing an increasingly international and competitive market (ETL, 2009). As meat is often sold as an undifferentiated product (Napolitano et al., 2007), the addition of supplementary quality cues could enable meat companies to differentiate their offerings and thus gain a competitive advantage.

Several studies have been conducted in order to reveal the preferences of consumers for food and meat attributes, and according to these food safety, the country of origin, organic production and animal welfare have been particularly requested attributes for meat (Loureiro and Umberger, 2007; Pouta et al., 2010; Schnettler et al., 2009). Many studies have highlighted the heterogeneity of consumer preferences (Chalak et al., 2008; Kornelis et al., 2010; Nilsson et al., 2006; Pouta et al., 2010). Animal welfare, healthiness and the environmental impacts of meat production and consumption have been increasingly addressed in both public and scientific discussion, but to the best of our knowledge there has been no research on the impact of carbon footprint information on the choice of a meat product. Consumer willingness to pay (WTP) plays an important role in product differentiation, as production costs may notably increase due to investments in distinct product attributes. Even providing information on product features is often costly.

The purpose of this study was to assess which product features of minced meat give consumers the greatest added value and to evaluate the impact of carbon footprint information on consumers' choices. The information obtained can help meat producers in adapting and differentiating their production to address the demand in a competitive market.

\section{Choice experiment model, data and design}

A choice experiment (CE) consists of several choice sets with two or more alternative goods described by their attributes. The respondent is asked to choose one of the alternative goods based on the differing product characteristics. According to Lancastrian consumer theory and random utility theory, these choices reveal consumer's trade-offs between the attributes of the goods (Bateman et al., 2002; Lancaster, 1966).

Random utility theory models the utility a consumer derives from a good by dividing it into a deterministic and a random component. When accounting for heterogeneity, the utility function becomes, according to Chalak et al. (2008) and Hu et al. (2004):

$$
U_{\text {nils }}=V_{\text {nils }}+e_{\text {nils }}=\beta_{\mathrm{s}} X_{\mathrm{ni}}+e_{\text {nils }}
$$

$U_{\text {nils }}$ is the utility that individual $\mathrm{n}$ in consumer class $\mathrm{s}$ obtains from good i. The deterministic component $V_{\text {nils }}$ is a linear function of attributes $X_{\text {ni }}$ of the good, where $\beta_{\mathrm{s}}$ is a vector of parameters for class s (Adamowicz et al., 1998; Bateman et al., 2002; Swait, 1994). The random part of the utility function $e_{\text {nils }}$ is an unobservable error term. It is assumed to be independently and identically distributed and to follow a type I extreme value distribution. (Bateman et al., 2002; Holmes and Adamowicz, 2003).

Econometric preference analysis is typically conducted using a conditional logit model (McFadden, 1974). However, the model assumes homogeneous preferences, or tastes, among consumers. A latent class model was therefore used in this study in order to account for differences in consumer preferences. These differences are reflected in the consumers' segment-specific choice behaviour. The latent class model reveals both the consumer segments and the relative preferences prevailing in each consumer class (Hu et al. 2004; Vermunt and Magidson, 2005). In this study, the consumer classes were determined purely based on the choices made by the individuals in the choice experiment. The relationship between the individual characteristics and the latent classes was only examined a posteriori of the actual estimation of the latent class model in order to describe the heterogeneous consumer classes (Vermunt and Magidson 2005).

Willingness to pay (WTP) is a measure for indicating the maximum monetary contribution an individual is willing to make in order to balance for a rise in his utility. Following Boxall and Adamowicz (2002), the general rule for class-specific estimates is:

$$
\mathrm{WTP}_{\mathrm{s}}=-\frac{1}{\beta_{p s}}\left[\ln \left(\sum_{j \in B}^{J} \exp \left(\beta_{\mathrm{s}} X_{\mathrm{j}}\right)\right)-\ln \left(\sum_{j \in B}^{J} \exp \left(\beta_{s}^{B} X_{\mathrm{j}}^{\mathrm{B}}\right)\right)\right] \text {, }
$$


where $X_{\mathrm{j}}$ and $X_{\mathrm{j}}^{B}$ represent the attribute levels of the product of interest and a baseline product. $\beta_{\mathrm{s}}^{B}$ is the coefficient for the attribute levels for class $\mathrm{s}$ for the baseline product and $\beta_{\mathrm{s}}$ respectively for the product of interest. $\beta_{\mathrm{ps}}$ is the price coefficient. The attribute impacts are summed over the $\mathrm{J}$ attributes of the products.

The data $(\mathrm{N}=1623)$ were gathered in March 2010 with an online questionnaire from consumers representative of Finnish Internet users, from 18 to 79 years old. The comparability of the survey sample with the population was at a reasonable level. The survey contained several question series examining different aspects of consumer attitudes towards meat products and production. The choice experiment was situated somewhat at the end of the questionnaire.

In the choice experiment, the respondents faced six choice sets, each set containing three minced meat alternatives and a no-choice option. The respondents were asked to imagine that they were buying minced meat for an everyday meal, and to choose which product they would buy or whether they would not buy any of the options.

Table 1 Minced meat attributes and levels used in the CE

\begin{tabular}{|c|c|}
\hline Attribute & Attribute levels and definition \\
\hline Price & $\begin{array}{l}\text { Range from } \\
€ 3 \text { to } € 20 / \mathrm{kg}\end{array}$ \\
\hline Meat type & $\begin{array}{l}\text { Pork } \\
\text { Mixed pork and beef (reference) } \\
\text { Beef }\end{array}$ \\
\hline $\begin{array}{l}\text { Carbon footprint } \\
\text { (Additional information on the meat } \\
\text { type presented only for subsample B) } \\
\text { - Greenhouse gas emissions. The } \\
\text { larger the carbon footprint, the more } \\
\text { harmful the impact on the climate. }\end{array}$ & $\begin{array}{l}\text { Small: greenhouse gas emissions: } 7 \text { carbon dioxide equivalents }(\mathrm{CO} 2 \mathrm{e}) / \mathrm{kg} \text { of meat } \\
\text { Average: greenhouse gas emissions: } 10 \mathrm{CO} 2 \mathrm{e} / \mathrm{kg} \text { of meat } \\
\text { Large: greenhouse gas emissions: } 20 \mathrm{CO} 2 \mathrm{e} / \mathrm{kg} \text { of meat }\end{array}$ \\
\hline Percentage of fat & $\begin{array}{l}\text { Maximum 5\% } \\
\text { Maximum } 10 \% \\
\text { Maximum 20\% } \\
\text { Not defined (reference) }\end{array}$ \\
\hline $\begin{array}{l}\text { Production method } \\
\text { - Feeding } \\
\text { - Consideration of animal welfare } \\
\text { - Control of animal disease prevention } \\
\text { and healthiness } \\
\text { - Transportation and butchery }\end{array}$ & $\begin{array}{l}\text { Organic } \\
\text { - Fed with organically produced fodder } \\
\text { - Animals have larger facilities than regulated and the possibility to behave in accordance with the } \\
\text { species (year-round outdoor recreation, stimulation) } \\
\text { - Endeavour to prevent animal diseases with good hygiene, health control and larger breeding spaces } \\
\text { - Transportation to the slaughterhouse } \\
\text { Animal welfare } \\
\text { - Fed with conventionally produced fodder } \\
\text { - Animals have larger facilities than regulated and the possibility to behave in accordace with the species } \\
\text { (year-round outdoor recreation, stimulation), keeping practices emphasizing animal welfare } \\
\text { - Healthiness and animal disease prevention is controlled in accordance with the law } \\
\text { - Butchery at the farm, in a small transferable slaughterhouse } \\
\text { Safety and healthiness } \\
\text { - Fed with conventionally produced fodder } \\
\text { - The conditions of the animals are in accordance with the law } \\
\text { - Strengthened safety and healthiness: } \\
\text { 1. Veterinarian's visitations more frequent than usual, 2.An anteroom that can be used as an area for } \\
\text { changing clean clothes and boots before entering the animal facilities, 3.Visitors are not allowed in } \\
\text { the production facilities, } 4 \text {.Breeding lots are kept in a separate compartment 5.Endeavour to avoid } \\
\quad \text { bringing animals to the farm from elsewhere } \\
\text { - Transportation to the slaughterhouse } \\
\text { Conventional (reference) } \\
\text { - Fed with conventionally produced fodder } \\
\text { - The conditions of the animals are in accordance with the law } \\
\text { - Healthiness and animal disease prevention is controlled in accordance with the law } \\
\text { - Transportation to the slaughterhouse }\end{array}$ \\
\hline
\end{tabular}

The minced meat products presented in each choice set had several attributes, the levels of which were varied across the alternatives. The levels of the more complex attributes were separately explained to the respondents before taking the choice experiment (Table 1). The price had 11 levels ranging from 3 to 20 euros per $\mathrm{kg}$, also stated in euros per $400 \mathrm{~g}$ package. The meat type attribute had three levels, the fat content four levels and the production methods four levels. The impact of carbon footprint information on consumer choice was tested by providing a sub-sample of consumers $(\mathrm{N}=803)$ with information on the footprint size. The carbon footprint size was fully associated with meat type as it was large in beef, small in pork and 
medium in mixed pork and beef. The only difference between the goods presented to the two sub-samples was therefore the extent of the information provided, while the goods per se were identical.

The division of the attribute level combinations into different choice set scenarios was determined using a random design in Sawtooth software. The total number of choice sets was 180. As each respondent faced six choice tasks, we ended up with 30 sample blocks.

In the modelling, price was treated as a continuous variable and the other attributes were coded as dummy variables. The impact of carbon footprint information was examined with a dummy variable indicating whether the footprint size was mentioned in the choice set, which was interacted with the meat type variables. In order to profile the heterogeneous consumer segments, the class membership of individuals was regressed on their socioeconomic characteristics, consumption habits and attitudes as exogenous variables using a logistic regression model.

\section{Results}

The conditional logit model illustrated the general consumer preferences for the product characteristics of minced meat (Table 2). The price coefficient was logically negative. Beef products were preferred over mixed beef and pork products, the latter of which were preferred over pure pork products. Organic production had the largest positive effect on product choice compared to animal welfare-oriented and safety and healthiness-oriented production methods. All of these methods were preferred to conventional production. The fat contents of 5\% and $10 \%$ had an even greater positive effect on the choice, whereas the impact of the fat content of $20 \%$ did not differ significantly from zero.

The latent class model divided consumers into groups that differed in their preferences (Table 2). The model was estimated with 1 to 7 consumer classes both with and without interactions. Based on the BIC values, the model with 6 consumer classes was selected. The consumer classes were rather clearly distinguished from each other. Consumers in Class 1 (23\% of the respondents) were named as the priceconscious consumers, whereas Class $2(20 \%)$ was fat-content conscious, having the strongest positive preferences for a low fat content and also deriving relatively high utility from responsible methods of production. The preference structure of Class $3(17 \%)$ was closest to the results of the conditional logit model. The class did not have the strongest preferences for any of the attributes compared to the other groups, but it could be qualified by a preference for beef products and a low fat content. Based on the logistic regressions, the respondents seemed to have somewhat ideological identities that were not, however, strongly reflected in their stated behaviour. Thus, they were named as the ideological but passive consumers. Class 4 (17\%) was rather indifferent to the product attributes compared to the other groups, having even slightly negative preferences towards organic production. Class $5(13 \%)$ was beef-preferring, having a strong positive preference for beef products, and Class $6(11 \%)$ methods of production-conscious, having strong positive preferences for methods of production deviating from the conventional, and in particular for organic production.

The interaction variables can be interpreted by comparing them to the original attribute levels. For instance, in the conditional logit model, interactions of the carbon footprint information and the two meat types suggested that information on the size of the carbon footprint had a highly significant impact on consumer choice. A small carbon footprint was seen as a better product characteristic than a large carbon footprint, as mentioning the large carbon footprint in the case of a beef product reduced the positive impact of the product type on consumer utility and made it less probable that the product was chosen. In the case of a pork product the impact was the opposite. In the latent class model the impact of the carbon footprint information on meat choice was rather large for classes 2, 3 and 6, and for the others was either nonsignificant or small.

The results of the six logistic regression models comparing each consumer segment in turn with the rest of the data revealed that age and attitudes towards animal welfare, environmental friendliness, healthiness and a low fat content were characteristics profiling most of the segments. For instance, the members of the ideological but passive consumer segment (Class 3) were profiled by frequently voting for the Green League and less frequently eating meat than respondents in the other segments.

The relative WTP estimates were calculated based on a simplified model including only footprint interactions. The relative WTP estimates for different products of interest in the case where no carbon footprint information was provided to the consumers were calculated separately for both meat types. A low fat content was the product feature for which consumers were willing to pay the highest premiums, but 
premiums for different methods of production also existed. On average, the WTP for organic production was the highest of these, being $5.6 \%$ for beef and $7.4 \%$ for pork. The WTP values followed preferences in consumer classes. For instance, the class valuing responsible methods of production (Class 6) had the highest WTP for the methods of production, being for organic production even $60 \%$ and animal welfare oriented production around $18 \%$. The fat content-conscious consumer class (Class 2) was willing to pay the most for a low fat content (around 40\%), and the ideological but passive consumer class (Class 3 ) had rather average relative WTP estimates compared to the other groups.

The respondents were in general willing to pay a little more for pork products and less for beef products when informed about the carbon footprint size, compared to not having this information. Consumer Classes 2, 3 and 6 were those most influenced by the carbon footprint information.

\section{Discussion and conclusions}

The results of this study suggest that a low fat content, in particular, is of great importance for consumers in Finland. This outcome is in line with the dietary developments and related nutritional policies, as promoting low-fat products has been the objective of persistent national health education and interventions in Finland (Prättälä, 2003). The health impacts of food have also been recognized to be very important in earlier studies (Chalak et al., 2008; Teratanavat and Hooker, 2006), but conversely to the findings of Pouta et al. (2010), organic production was generally appreciated more highly than animal welfare. The relatively low importance of price to the consumer segments may be related to bias caused by the hypothetical setting of the choice experiment. On the other hand, it may also be a signal that there could be potential for gains from greater differentiation of minced meat products than is currently put to use. However, it would be interesting to run a similar analysis with revealed preference data in order to examine the scale of hypothetical bias in the estimates.

Heterogeneity in consumer preferences was discovered, and the six consumer segments revealed by this analysis included a price-conscious, a fat content-conscious, an ideological but passive, and an indifferent consumer group, a group preferring beef products and a group that was conscious of the different methods of production. The identification of the ideological but passive consumer segment suggests that it is not enough for the consumers to have ideological attitudes, but that there have to be stronger incentives that promote the buying of food produced in a responsible way, in order to actually affect consumer choice.

Finnish meat processors could make use of product differentiation, as in addition to the rather high WTP for a low fat content, particular segments were willing to pay significant premiums for organic and to some extent animal welfare-oriented production. Organic and animal welfare-oriented production could in fact provide processors with an even greater competitive advantage than the low fat content, the latter of which can be reproduced rather easily by competitors. However, defining and measuring animal welfareoriented production, in particular, remains a challenge for meat companies.

Information on the carbon footprint generally had a significant impact on consumer choice, influencing meat type-specific consumer preferences: beef products have a larger carbon footprint than pork products, and consequently their popularity decreased when footprint information was presented to the consumers. This impact on the WTP estimates varied across the consumer segments, although overall the impact was relatively low. The carbon footprint size could be a complicated matter for Finnish consumers to understand and process, as only a small number of food products currently contain this information. The possibilities for differentiation provided by carbon footprint information should be further examined.

Although providing information on the carbon footprint size had an impact on the stated choices of consumers in this study, increasing environmental consciousness could in the future itself induce similar choice patterns within some consumer segments, even without explicit carbon footprint information on the products. This would increase the demand for pork at the expense of beef. Increasing consumption of poultry, meat substitutes and vegetables could also be seen as a potential future development in this regard. Meat companies could thus think of new ways to produce alternative products with smaller environmental impacts or other differentiated features, as a response to potentially shifting demand within particular consumer segments. 
SUOMEN MAATALOUSTIETEELLISEN SEURAN TIEDOTE NRO 28

Table 2 Conditional logit and latent class models for minced meat choice

\begin{tabular}{|c|c|c|c|c|c|c|c|c|c|}
\hline \multirow[t]{2}{*}{ MODELS FOR CHOICES } & \multirow{2}{*}{$\begin{array}{r}\text { Conditional } \\
\text { Overall }\end{array}$} & \multicolumn{8}{|c|}{ Latent class model } \\
\hline & & Class 1 & Class 2 & Class 3 & Class 4 & Class 5 & Class 6 & Overall & \\
\hline Pseudo R ${ }^{2}$ & 0.105 & 0.3721 & 0.3639 & 0.1427 & 0.1797 & 0.4575 & 0.3598 & 0.4546 & \\
\hline Class Size & & 0.2322 & 0.1985 & 0.1708 & 0.1653 & 0.1256 & 0.1075 & & \\
\hline \multirow[t]{3}{*}{ ATTRIBUTES \& INTERACTIONS } & Conditional & \multicolumn{8}{|c|}{ Latent class model } \\
\hline & & $\begin{array}{l}\text { Price- } \\
\text { conscious }\end{array}$ & $\begin{array}{l}\text { Fat content- } \\
\text { conscious }\end{array}$ & $\begin{array}{l}\text { Ideological but } \\
\text { passive }\end{array}$ & Indifferent & $\begin{array}{l}\text { Beef- } \\
\text { preferring }\end{array}$ & $\begin{array}{l}\text { Methods of production- } \\
\text { conscious }\end{array}$ & $\begin{array}{l}\text { Wald } \\
\text { p-value }\end{array}$ & $\begin{array}{l}\text { Wald }(=) \\
\text { p-value }\end{array}$ \\
\hline & \multicolumn{9}{|c|}{ coefficients and significance levels } \\
\hline ASC 1 & 0.00 & 0.00 & 0.00 & 0.00 & 0.00 & 0.00 & 0.00 & 0.00 & 0.00 \\
\hline ASC 2 & $0.10 * *$ & -0.10 & 0.05 & 0.18 & $0.41 * *$ & 0.11 & 0.09 & & \\
\hline ASC 3 & 0.03 & -0.11 & -0.08 & 0.11 & $0.25 *$ & 0.04 & $0.25^{\circ}$ & & \\
\hline ASC 4 & $-0.16 *$ & $-5.26 * *$ & $0.92 * *$ & $3.89 * *$ & $-1.67 * *$ & $2.27 * *$ & -0.65 & & \\
\hline Price & $-0.09 * *$ & $-0.35 * *$ & $-0.06 * *$ & $-0.04^{\circ}$ & -0.02 & -0.03 & $-0.09 * *$ & 0.00 & 0.00 \\
\hline Beef & $0.32 * *$ & $-0.66 *$ & -0.16 & $1.36 * *$ & $-0.73 *$ & $4.57 * *$ & -0.09 & 0.00 & 0.00 \\
\hline Pork & $-0.76 * *$ & $-1.07 * *$ & $-0.37 *$ & $-1.21 * *$ & $-1.55 * *$ & $-0.79 *$ & $-1.50 * *$ & 0.00 & 0.00 \\
\hline Safety and healthiness & $0.46 * *$ & $0.45 * *$ & $0.77 * *$ & 0.32 & $0.31 *$ & 0.25 & $1.16 * *$ & 0.00 & 0.02 \\
\hline Animal welfare & $0.67 * *$ & $0.63 * *$ & $1.13 * *$ & $0.62 * *$ & $0.34^{\circ}$ & $0.87 * *$ & $1.78 * *$ & 0.00 & 0.00 \\
\hline Organic & $0.79 * *$ & $0.84 * *$ & $1.44 * *$ & $1.35 * *$ & -0.17 & $1.30 * *$ & $4.08 * *$ & 0.00 & 0.00 \\
\hline Fat content $5 \%$ & $1.15 * *$ & $1.23 * *$ & $3.59 * *$ & $2.27 * *$ & $0.64 * *$ & $1.79 * *$ & $0.45^{\circ}$ & 0.00 & 0.00 \\
\hline Fat content $10 \%$ & $1.05 * *$ & $1.17 * *$ & $2.89 * *$ & $1.78 * *$ & $0.91 * *$ & $1.77 * *$ & $0.74 * *$ & 0.00 & 0.00 \\
\hline Fat content $20 \%$ & 0.05 & 0.16 & $0.70 * *$ & -0.23 & $-0.29^{\circ}$ & $0.44 *$ & 0.11 & 0.00 & 0.01 \\
\hline Pork \& Animal welfare & -0.04 & $0.63 * *$ & 0.00 & 0.59 & $-0.95 * *$ & -0.03 & 0.40 & 0.00 & 0.00 \\
\hline Beef \& Animal welfare & $-0.14^{\circ}$ & - & - & - & - & - & - & - & - \\
\hline Pork \& Safety and health. & - & $0.20^{\circ}$ & $0.20^{\circ}$ & $0.20^{\circ}$ & $0.20^{\circ}$ & $0.20^{\circ}$ & $0.20^{\circ}$ & 0.07 & c.i. \\
\hline Beef \& Safety and health. & - & $0.20 *$ & $0.20 *$ & $0.20 *$ & $0.20 *$ & $0.20 *$ & $0.20 *$ & 0.05 & c.i. \\
\hline Pork \& Price & 0.00 & - & - & - & - & - & - & - & - \\
\hline Beef \& Price & 0.01 & $0.07 *$ & 0.01 & 0.02 & -0.02 & $-0.06 *$ & 0.00 & 0.04 & 0.02 \\
\hline Organic \& Price & $-0.01^{\circ}$ & $-0.04 * *$ & $-0.04 * *$ & $-0.04 * *$ & $-0.04 * *$ & $-0.04 * *$ & $-0.04 * *$ & 0.00 & c.i. \\
\hline Fat content $5 \%$ \& Price & -0.01 & $-0.02 *$ & $-0.02 *$ & $-0.02 *$ & $-0.02 *$ & $-0.02 *$ & $-0.02 *$ & 0.04 & c.i. \\
\hline Fat content $10 \%$ \& Price & $-0.02 *$ & $-0.03 * *$ & $-0.03 * *$ & $-0.03 * *$ & $-0.03 * *$ & $-0.03 * *$ & $-0.03 * *$ & 0.00 & c.i. \\
\hline Footprint \& Price & 0.00 & - & - & - & - & - & - & - & - \\
\hline Footprint \& Beef & $-0.59 * *$ & -0.25 & $-1.77 * *$ & $-1.19 * *$ & -0.44 & $-0.77 *$ & $-1.49 * *$ & 0.00 & 0.00 \\
\hline Footprint \& Pork & $0.44 * *$ & $0.38^{\circ}$ & $1.09 * *$ & $0.95 * *$ & -0.06 & 0.25 & $1.23 * *$ & 0.00 & 0.01 \\
\hline
\end{tabular}

was class independent. 


\section{References}

Adamowicz, W., Louviere, J. \& Swait, J. 1998. Introduction to attribute-based stated choice methods, Final Report submitted to Resource Valuation Branch. Damage Assessment Center, NOAA, Edmonton.

Bateman, I., Carson, R., Day, B., Hanemann, M., Hanley, N., Hett, T., Jones-Lee, M., Loomes, G., Mourato, S., Özdemiroglu, E., Pearce, D., Sugden, R., \& Swanson, J. 2002. Economic valuation with stated preference techniques: a manual. Cheltenham, UK: Edward Elgar.

Boxall, P., \& Adamowicz, W. 2002. Understanding heterogeneous preferences in Random Utility Models: A Latent Class Approach. Environmental and Resource Economics, 23(4), 421-446.

Chalak, A., Balcombe, K., Bailey, A. \& Fraser, I. 2008. Pesticides, Preference Heterogeneity and Environmental Taxes. Journal of Agricultural Economics, 59(3), 537-554.

ETL 2009. Elintarvikkeiden tuonti 1995,2000 ja 2005 - 2009. Vienti- ja tuontitilastot, Elintarviketeollisuusliitto. [Foodstuff imports 1995, 2000 and 2005 - 2009, Finnish Food and Drinks Industries' Federation.] URL http://www.etl.fi/www/fi/tilastot/vienti-_ja_tuontitilastot.php, 15.10.2010.

Forsman-Hugg, S., Katajajuuri, J. -M., Pesonen, I., Paananen, J., Mäkelä, J., \& Timonen, P. 2008. Building the content for CSR in the food chain with a stakeholder dialogue. In European Association of the Agricultural Economists. XIIth Congress of the European Association of the Agricultural Economists. People, Food and Environments: Global Trends and European Strategies.

Holmes, T. \& Adamowicz, W. 2003. Attribute-based methods. In Champ, P., A., Boyle K., J. \& Brown T., S. (Eds.). A primer on nonmarket valuation - the economics of non-market goods and resources (Chapter 4, pp. 99-110). Dordrecht: Kluwer Academic Publishers.

Hu, W., Hunnemeyer, A., Veeman, M., Adamowicz, W., \& Srivastava, L. 2004. Trading off health, environmental and genetic modification attributes in food. European Review of Agricultural Economics, 31(3), 389-408.

Kornelis, M., van Herpen, E., van der Lans, I., \& Aramyan, L. 2010. Using non-food information to identify foodchoice segment membership. Food Quality and Preference, 21(5), 512-520.

Lancaster, K. (1966). A new approach to consumer theory. The Journal of Political Economy, 74(2), 132-157.

Loureiro, M., \& Umberger, W. 2007. A choice experiment model for beef: What US consumer responses tell us about relative preferences for food safety, country-of-origin labeling and traceability. Food Policy, 32(4), 496-514

McFadden, D. 1974. Conditional Logit Analysis of qualitative choice behavior. In P. Zarembka (Eds.), Frontiers in econometrics, 105-142. New York: Academic Press.

Napolitano, F. Caporale, G., Carlucci, A., \& Monteleone, E. 2007. Effect of information about animal welfare and product nutritional properties on acceptability of meat from Podolian cattle. Food Quality and Preference, 18(2), 305312 .

Nilsson, T., Foster, K., \& Lusk, J. L. 2006. Marketing opportunities for certified pork chops. Canadian Journal of Agricultural Economics, 54(4), 567-583.

Pouta, E., Heikkilä, J., Forsman-Hugg, S., Isoniemi, M., \& Mäkelä, J. 2010. Consumer choice of broiler meat: the effects of country of origin and production methods. Food Quality and Preferences, 21(5), 539-546.

Prättälä, R. 2003. Dietary changes in Finland - success stories and future challenges. Appetite, 41(3), $245-\mathrm{s} 249$.

Schnettler, B., Vidal, R., Silva, R., Vallejos, L., \& Sepulveda, N. 2009. Utility to consumers and consumer acceptance of information on beef kabels in Southern Chile. Chilean Journal of Agricultural Research, 69(3), 373-382.

Swait, J. 1994. A structural equation model of latent segmentation and product choice for cross-sectional revealed preference choice data. Journal of Retailing and Consumer Services, 1(2), 77-89.

Teratanavat, R., \& Hooker, N. H. 2006. Consumers valuations and preference: heterogeneity for a novel functional food. Journal of Food Science, 71(7), 533-541.

Vermunt J. K., \& Magidson, J. 2005. Latent GOLD® Choice 4.0 User's Manual, Copyright @ 2005 by Statistical Innovations, Inc. 